\title{
TOTAL OMENTECTOMY IN GASTRIC CANCER SURGERY: IS IT ALWAYS NECESSARY?
}

\author{
Omentectomia total na cirurgia do câncer gástrico: É ela sempre necessária? \\ Leandro Cardoso BARCHI ${ }^{1}$, Marcus Fernando Kodama Pertille RAMOS ${ }^{1}$, André Roncon DIAS ${ }^{1}$, \\ Osmar Kenji YAGI ${ }^{1}$, Ulysses RIBEIRO-JÚNIOR', Bruno ZILBERSTEIN'1 Ivan CECCONELLO'
}

How to cite this article: Barchi LC, Ramos MFKP, Dias AR, Yagi OK, Ribeiro-Júnior U, Zilberstein B, Cecconello I. Total omentectomy in gastric cancer surgery: Is it always necessary? ABCD Arq Bras Cir Dig. 2019;32(1):e1425. DOI: /10.1590/0102-672020180001e1425

From the ${ }^{1}$ Disciplina de Cirurgia do Aparelho Digestivo, Departamento de Gastroenterologia, Faculdade de Medicina, Universidade de São Paulo ('Discipline of Digestive Surgery, Department of Gastroenterology, Faculty of Medicine, University of São Paulo), São Paulo, SP, Brazil

HEADINGS-Gastric neoplasms. Recurrence. Lymph node excision. Gastrectomy. Adenocarcinoma. Omentum.
ABSTRACT - Background: Traditionally, total omentectomy is performed along with gastric resection and extended lymphadenectomy in gastric cancer (GC) surgery. However, solid evidences regarding its oncologic benefit is still scarce. Aim: To evaluate the incidence of metastatic omental lymph nodes $(\mathrm{LN})$ in patients undergoing curative gastrectomy for $\mathrm{GC}$, as well as its risk factors and patients' outcomes. Methods: All consecutive patients submitted to D2/modified D2 gastrectomy due to gastric adenocarcinoma from March 2009 to April 2016 were retrospectively reviewed from a prospective collected database. Results: Of 284 patients included, five (1.8\%) patients had metastatic omental LN (one: pT3N3bM0; two: pT4aN3bM0; one: pT4aN2M0 and one pT4bN3bM0). Four of them deceased and one was under palliative chemotherapy due relapse. LN metastases in the greater omentum significantly correlated with tumor's size $(p=0.018), \mathrm{N}$ stage $(p<0.001)$, clinical stage $(p=0.022)$, venous invasion growth $(p=0.003)$, recurrence $(p=0.006)$, site of recurrence (peritoneum: $p=0.008$; liver: $p=0.023$; ovary: $p=0.035)$ and death $(p=0.008)$. Conclusion: The incidence of metastatic omental LN of patients undergoing radical gastrectomy due to GC is extremely low. Total omentectomy may be avoided in tumors smaller than $5.25 \mathrm{~cm}$ and $\mathrm{T} 1 / \mathrm{T} 2$ tumors. However, the presence of lymph node metastases in the greater omentum is associated with recurrence in the peritoneum, liver, ovary and death

\section{Correspondence:}

Leandro Cardoso Barchi

E-mail: leandrobarchi@hotmail.com

Financial source: none

Conflict of interest none

Received for publication: $27 / 07 / 2018$

Accepted for publication: 22/11/2018

DESCRITORES - Neoplasias gástricas Recidiva. Excisão de linfonodo. Gastrectomia. Adenocarcinoma. Omento.
RESUMO - Racional: Tradicionalmente a omentectomia total é realizada juntamente com a ressecção gástrica associada à linfadenectomia na cirurgia do câncer gástrico. No entanto, evidências sólidas em relação ao seu benefício oncológico são escassas. Objetivo: Avaliar a incidência de metástases em linfonodos do omento maior em pacientes submetidos à gastrectomia potencialmente curativa por câncer gástrico, assim como, avaliar os fatores de risco para a ocorrência e a evolução dos pacientes. Métodos: Pacientes consecutivos submetidos à gastrectomia D2/D2 modificada devido ao adenocarcinoma gástrico foram analisados retrospectivamente a partir de um banco de dados. Resultados: Dos 284 pacientes, cinco $(1,8 \%)$ tinham linfonodos metastáticos no omento maior (um pT3N3bM0; dois pT4aN3bM0; um pT4aN2M0 e um pT4bN3bM0). Quatro faleceram e um estava em tratamento paliativo com quimioterapia devido à recidiva da doença. Os linfonodos metastáticos no omento maior tiveram correlação significativa com o tamanho do tumor $(p=0,018)$, estádio $N(p<0,001)$, estádio clínico $(p=0,022)$, invasão venosa $(p=0,003)$, recorrência $(p=0,006)$, local de recorrência (peritônio $p=0,008$; fígado $p=0,023$; ovário $p=0,035)$ e óbito $(p=0,008)$. Conclusão: $\mathrm{A}$ incidência de linfonodos metastático no omento maior de pacientes submetidos à gastrectomia radical por câncer gástrico é baixa. A omentectomia total pode ser evitada em tumores menores que $5,25 \mathrm{~cm}$ e estádios $\mathrm{T} 1 / \mathrm{T} 2$. Entretanto, a presença de metástases linfonodais no omento maior está associada à recidiva no peritônio, fígado, ovário e óbito. he prognostic relevance of the multimodal treatment in gastric cancer (GC) has been well stablished ${ }^{30}$. However, surgery remains the only possibility of cure, especially when is associated with early diagnosis ${ }^{18,32}$. It is also known that the lymph node (LN) involvement is the main prognostic factor after potential curative resection $(\mathrm{R} 0)^{28}$. Thus, systematic removal of $\mathrm{LN}$ is considered crucial in GC surgery and the number of harvested LN as a direct measure of the quality of surgery ${ }^{3,38}$.

The greater omentum (including the omental sac) is removed in block among with LN in this type of operation. It is believed that total omentectomy (TO) is essential to ensure the elimination of cancer cells during advanced GC surgery ${ }^{11}$. However, the greater omentum plays an important role in the peritoneal primary defense. Therein are the milky spots (mesenchymal cells covered by a mesothelium layer containing macrophages (70\%), B lymphocytes (10\%), T lymphocytes (10\%) and mast cells. The omentum reduces intestinal adhesions and prevents free peritonitis. Patients who undergo to TO are more vulnerable to peritoneal infections, which are often associated with worse clinical outcomes ${ }^{4,26}$. Further, it has been reported that long-term overall survival (OS) does not differ between patients undergoing total or partial omentectomy (PO), whereas the incidence of complications is higher in the TO patients ${ }^{9,36}$.

There is no consensus regarding the oncologic value of omentectomy in GC surgery between the European, American and Japanese guidelines. The European 
guideline provides no guidance on this subject ${ }^{34}$, whereas the American guidelines recommend resection of the greater and lesser omentum ${ }^{1}$. Alternatively, the Japanese Gastric Cancer Association (JGCA) guidelines recommend the preservation of the omentum $3 \mathrm{~cm}$ distal to gastroepiploic vessels in patients with $\mathrm{T} 1 / \mathrm{T} 2$ stage tumors and $\mathrm{TO}$ in $\mathrm{T} 3 / \mathrm{T} 4$ tumors $^{19}$. Its pivotal role is not discussed when there is a suspicion or evident metastatic invasion of the greater omentum. However, the unnecessary impact of TO might be substantial.

In this context, over the past few years, laparoscopic gastrectomy has become an alternative procedure for early GC patient ${ }^{19}$. Studies are underway to confirm its efficacy in more advanced forms ${ }^{16,17}$. In open surgery, the dissection of the greater omentum through the avascular plane of the transverse colon can lead to TO quickly and satisfactorily. However, the complete resection of the greater omentum during laparoscopic gastrectomy is associated with longer operative time and higher risks of adjacent organs injury, without interfering in the recurrence or in the disease specific survival ${ }^{21}$.

There is a possibility that the LN in the greater omentum may be spared of metastatic involvement in GC patients. Therefore, this part of the procedure could be omitted, mainly in minimally invasive surgery, reducing surgical time and avoiding complications.

This study aimed to evaluate the incidence of metastatic $L N$ in the greater omentum of patients who underwent radical gastrectomy for $\mathrm{GC}$, as well as its risk factors and patients' outcomes.

\section{METHODS}

The study was approved by the hospital ethics committee (NP898/2016) and registered at "Plataforma Brasil" (CAAE: 56307516.9.0000.0068) that collects all research projects that involve human beings in country.

\section{Patients}

We retrospectively reviewed all patients submitted to R0 gastrectomy due to gastric adenocarcinoma from March 2009 to April 2016 from a prospective collected database. Patients with gastric stump neoplasia, histological type different from adenocarcinoma, macroscopic metastatic involvement of the greater omentum (carcinomatosis), distant metastasis and emergency surgeries were excluded from the analysis.

Patients were staged in the preoperatively through abdominal/pelvis computed tomography, endoscopy and laboratory tests. Extension of gastric resection (total $x$ subtotal) was based on the location of the tumor to obtain free proximal margin ${ }^{37}$. TNM staging was performed according to the TNM $7^{\text {th }}$ edition ${ }^{8}$

All cases were operated in a high-volume center by surgeons with extensive experience in the surgical management of GC. The surgical technique, extension of resection and dissection of LN chains followed the recommendations of the JGCA guidelines ${ }^{19}$. Total omentectomy and D2 lymphadenectomy was performed in all patients. Digestive tract was reconstructed through Rouxen-Y anastomosis. The survival status was assessed during follow-up. Patients without medical consultations for over one year were considered as the loss of follow-up. The type of recurrence was classified as peritoneal, local (lymph node or anastomosis) and distant (liver, ovary, lung, bone and others).

\section{Pathological analysis}

Routinely, at the end of each operation, the surgical specimen was prepared by a member of the surgical team. The omentum was divided from the specimen distally to the gastroepiploic vessels (LN station number 4, Figure 1). The LN stations and the omentum were sent in separate flasks for histopathological analysis. The materials were fixed in $10 \%$ formaldehyde for 24-48 $h$, and then analyzed. The tumor was described in order to characterize its size, location (antrum, body, proximal or diffuse), the Borrmann classification and the resection margins. All material was meticulously evaluated macroscopically, particularly to seek for implants. Through the visualization, palpation and section, the LN stations and the greater omentum were dissected to search for LN. When they were found, were described in terms of number, size and external macroscopic appearance. The LN larger than $0.6 \mathrm{~cm}$ were sliced and shown alone in a paraffin block. The other $L N$ were represented together in a paraffin block. If suspected implant area was visualized, this area was described and represented. If no change was seen, about 3-5 cuts were performed.

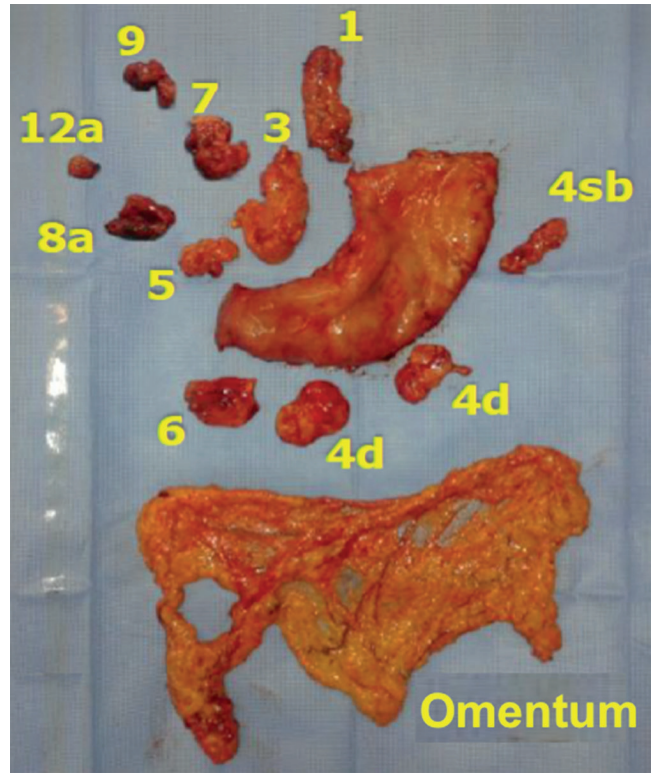

FIGURE 1 - Surgical specimen of subtotal gastrectomy with the greater omentum and lymph node chains dissected and sent in separate for histopathological analysis

The slides were stained by the $\mathrm{H} \& \mathrm{E}$ method and evaluated by the pathologist in a conventional optical microscope.

\section{Statistical analysis}

The numerical variables were described by mean and standard deviation (SD) or median and quartiles, minimum and maximum values. The categorical variables were described by absolute and relative frequencies. The association between the LN involvement in the greater omentum with categorical variables was investigated by Fisher's exact test or chi-square test and numerical variables by Wilcoxon-Mann-Whitney tests. The ROC (Receiver Operating Characteristic) curve was constructed to determine the cut-off of tumor's size. The analysis was performed by SPSS ${ }^{\circledR}$ software version 18 , adopting the significance level of $5 \%$.

\section{RESULTS}

Of the total of 346 patients, 62 (17.9\%) were excluded, who did not meet the inclusion/exclusion criteria of the study and were: 26 (41.9\%) because they underwent degastrectomy; 12 (19.7\%) had no adenocarcinoma (histopathological analysis revealed GIST and neuroendocrine tumor); eight (13.1\%) had less than 15 LN harvested in the operation; seven (11.4\%) had no tumor found in anatomopathological analysis (post-margins compromised in endoscopic resections); five (8.2\%) had direct invasion of the omentum, three (4.9\%) had distant metastasis (M1) and one (1.6\%) had a synchronous tumor (colon neoplasia). After the exclusions, the study sample consisted of 284 patients. 
TABLE 1 - Baseline characteristics and perioperative results $(n=284)$

\begin{tabular}{l|c|}
\hline Gender & $n(\%)$ \\
\hline Male & $159(55.9)$ \\
\hline Female & $125(44.1)$ \\
\hline BMI kg/m² (min-max) & $24.6(14-46.5)$ \\
\hline $\begin{array}{l}\text { Resection } \\
\text { Subtotal }\end{array}$ & $182(64.1)$ \\
\hline Total & $102(35.9)$ \\
\hline Approach & \\
\hline Conventional & $253(89.1)$ \\
\hline Laparoscopic & $16(5.6)$ \\
\hline Robotic & $7(2.5)$ \\
\hline Hybrid & $8(2.8)$ \\
\hline Site of tumor & \\
\hline Diffuse & $6(2.1)$ \\
\hline Antrum & $185(65.2)$ \\
\hline Body & $55(19.3)$ \\
\hline Proximal & $38(13.3)$ \\
\hline Borrmann classification * \\
I
\end{tabular}

TABLE 2 - Surgery with multivisceral resection in the sample $(n=284)$

\begin{tabular}{|l|c|}
\hline Mesocolon - anterior sheet & $\mathrm{n}(\%)$ \\
\hline No & $90(31.6)$ \\
\hline Incomplete & $29(10.2)$ \\
\hline Yes & $165(58.1)$ \\
\hline Pancreatic capsule & $96(33.8)$ \\
\hline No & $37(13)$ \\
\hline Incomplete & $151(53.1)$ \\
\hline Yes & \\
\hline Oncologic splenectomy & $270(95.1)$ \\
\hline No & $14(4.9)$ \\
\hline Yes & $282(99.2)$ \\
\hline Tactical splenectomy & $2(0.8)$ \\
\hline No & $281(98.9)$ \\
\hline Yes & $3(1.1 \%)$ \\
\hline Hepatectomy & \\
\hline No & $278(97.8)$ \\
\hline Yes & $6(2.2)$ \\
\hline Colectomy & $274(96.4)$ \\
\hline No & $10(3.6)$ \\
\hline Yes & $283(99.6)$ \\
\hline Pancreatectomy & $1(0.4)$ \\
\hline No & \\
\hline Yes & \\
\hline Resection of the diaphragm & \\
\hline No & \\
\hline Yes & \\
\hline
\end{tabular}

There was a male preponderance of 159 (55.9\%) patients, with a mean age of 61.8 years $( \pm 11.9 ; 25-86)$. The mean body mass index (BMI) was $24.6 \mathrm{~kg} / \mathrm{m}^{2}( \pm 4.7 ; 14-46.5)$. Subtotal gastrectomy was performed in 182 (64.1\%). The tumor was located at the antrum in 185 (65.2\%). Forty (14.1\%) patients received neoadjuvant chemotherapy. Open surgery was performed in 253 (89.1\%). Thirty-day mortality was 3.1\% (nine patients). The median follow-up period for all patients was 27.6 months (189.5). The median follow-up time of the disease-free patients was 34.3 months (1-89.5). The baseline characteristics of patients and the perioperative results are shown in Table 1. The pathological analysis is summarized in Table 3. Peritoneal washing was negative in all patients. The average number of LN resected was $41.2( \pm 17 ; 15-114)$. The average number of positive LN was 4.69 ( $\pm 8.12 ; 0-53)$. The Lymph Node Ratio (LNR) was $0.113( \pm 0.447 ; 0-0.96)$. The intestinal histological type of Lauren occurred in 146 (51.4\%) patients. Poorly differentiated tumors were also 146 (51.4\%). Sixty-six (23.2\%) had at least one $\mathrm{LN}$ in the greater omentum. Metastatic LN were found in five (1.8\%) patients (one: pT3N3bM0; two: pT4aN3bM0; one: pT4aN2M0 and one pT4bN3bM0). The mean size of tumors of patients without metastatic omental LN was $4.8 \mathrm{~cm}( \pm 2.96 ; 0.5-$ $14.5)$, while the mean size of tumors of patients with metastatic LN was $8.06 \mathrm{~cm}( \pm 2.75 ; 2.75-9, \mathrm{p}=0.018)$. The cut-off point was $5.25 \mathrm{~cm}$ (area under the curve: 0.8072; IC95\%: 0.6645-0.9498, Figure 2). Metastatic LN in the greater omentum was significantly correlated with $N$ stage $(p<0.001)$, clinical stage $(p=0.022)$ and venous invasion growth $(p=0.003)$.

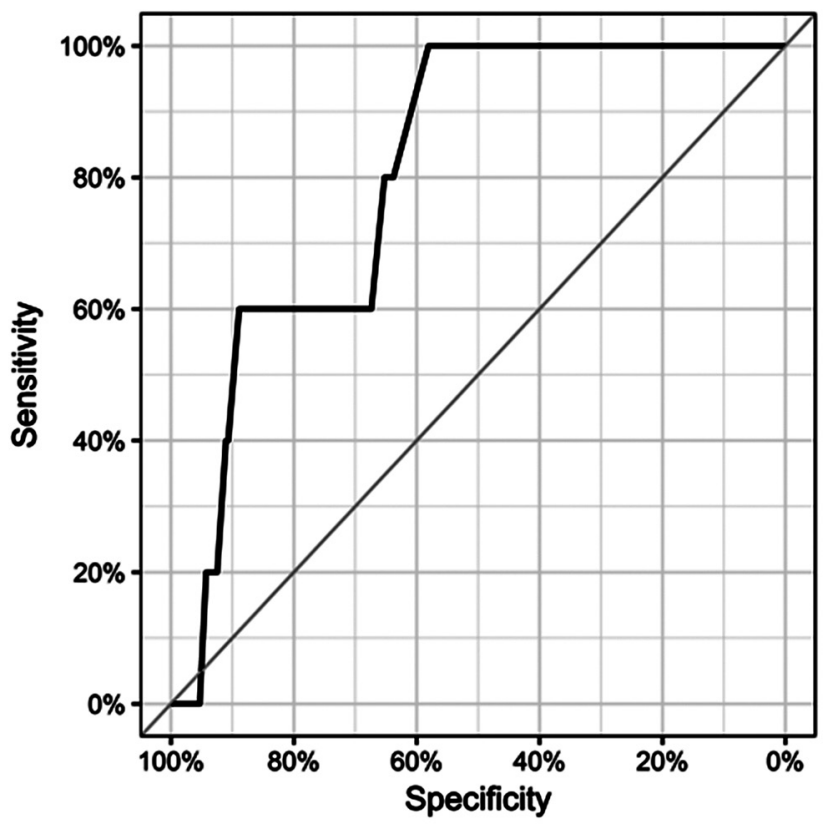

Cutt-off $=5.25 \mathrm{~cm}$; specificity $=65.2 \%$; sensitivity $=80 \%$; negative predictive value $=99.4 \%$; positive predictive value $=3.96 \%$; accuracy $=65.4 \%$

FIGURE 2 - The area under the ROC curve (0.8072 - (IC95\%:0.6645 - 0.9498) shows that patients with metastatic LN in the omentum have larger tumors

During the follow-up period 163 (57.4\%) were free of the disease. The cancer relapse was found in 65 (22.8\%) patients and the most frequent site was in the peritoneum (46.2\%). Four patients with metastatic omental LN died and the other one was under palliative chemotherapy due to the relapse on the liver and pleura. We found association between metastatic LN in the omentum with recurrence $(p=0.006)$, site of recurrence (peritoneum: $p=0.008$; liver: $p=0.023$; ovary: $p=0.035$ ) and death $(p=0.008$, Table 4$)$.

Patients who did not relapse prior to loss of follow-up or in whom this data was unavailable were removed from the sample. For this analysis, 228 patients remained. 
TABLE 3 - Pathological analysis according to lymph node involvement in the greater omentum

\begin{tabular}{|c|c|c|c|c|}
\hline & \multicolumn{3}{|c|}{ Metastatic omental LN } & \\
\hline & Total $(n=284)$ & No $(n=279)$ & Yes $(n=5)$ & \\
\hline \multicolumn{5}{|l|}{ pT stage } \\
\hline $\mathrm{T} 1 / \mathrm{T} 2$ & 116 & $116(41.6)$ & $0(0)$ & \multirow{2}{*}{$p_{1}=0.081$} \\
\hline T3/T4 & 168 & $163(58.4)$ & $5(100)$ & \\
\hline \multicolumn{5}{|l|}{ pN stage } \\
\hline N0 / N1 & 162 & $162(57.8)$ & $0(0)$ & \multirow{4}{*}{$\mathrm{p}_{1}<0.001$} \\
\hline N2 & 60 & $59(21.1)$ & $1(20)$ & \\
\hline N3a & 36 & $36(12.9)$ & $0(0)$ & \\
\hline N3b & 27 & $23(8.2)$ & $4(80)$ & \\
\hline \multicolumn{5}{|l|}{ Clinical stage } \\
\hline I/ II / IIIA & 205 & $205(73.5)$ & $0(0)$ & \multirow{3}{*}{$p_{1}=0.022$} \\
\hline IIIB & 41 & 39 (13.9) & $2(40)$ & \\
\hline IIIC & 38 & $35(12.5)$ & $3(60)$ & \\
\hline Tumor size $(\mathrm{cm})^{\&}$ & 4.3 & 4.8 & 8.06 & $p_{1}=0.018$ \\
\hline \multicolumn{5}{|l|}{ Lauren classification } \\
\hline Intestinal & 146 & $145(52)$ & $1(20)$ & \\
\hline Diffuse & 108 & $105(37.6)$ & $3(60)$ & $\mathrm{p}_{1}=0.290$ \\
\hline Mixed & 30 & $29(10.4)$ & $1(20)$ & \\
\hline \multicolumn{5}{|l|}{ Differentiation grade } \\
\hline Well differentiated & 22 & $21(7.5)$ & $1(20)$ & \\
\hline Mod. differentiated & 116 & $116(41.6)$ & $0(0)$ & $p_{1}=0.098$ \\
\hline Poorly differentiated & 146 & $142(50.9)$ & $4(80)$ & \\
\hline \multicolumn{5}{|l|}{ Lymphatic invasion growth * } \\
\hline Yes & 143 & $138(49.5)$ & $5(100)$ & $\mathrm{p}_{1}=0.060$ \\
\hline No & 140 & $140(50.5)$ & $0(0)$ & \\
\hline \multicolumn{5}{|l|}{ Venous invasion growth * } \\
\hline Yes & 48 & $44(15.8)$ & $4(80)$ & $p_{1}=0.003$ \\
\hline No & 235 & $234(82.2)$ & $1(20)$ & \\
\hline \multicolumn{5}{|l|}{ Perineural invasion growth * } \\
\hline Yes & 140 & $136(48.7)$ & $4(80)$ & $p_{1}=0.211$ \\
\hline No & 143 & $142(51.3)$ & $1(20)$ & \\
\hline \multicolumn{5}{|l|}{ Intestinal metaplasia } \\
\hline Yes & 133 & $130(46.6)$ & $3(60)$ & $\mathrm{p}_{3}=0.552$ \\
\hline No & 151 & $149(53.4)$ & $2(40)$ & \\
\hline \multicolumn{5}{|l|}{ Tumor site } \\
\hline Antrum & 28 & $182(65.2)$ & $3(60)$ & \\
\hline Body & 55 & $55(19.7)$ & $0(0)$ & $p_{1}=0.279$ \\
\hline Proximal & 135 & $36(12.9)$ & $2(40)$ & \\
\hline Diffuse & 56 & $6(2.1)$ & $0(0)$ & \\
\hline \multicolumn{5}{|l|}{ Neoadjuvant therapy } \\
\hline Yes & 40 & $39(14)$ & $1(20)$ & \\
\hline No & 244 & $240(86)$ & $4(80)$ & \\
\hline \multicolumn{5}{|l|}{ Gastrectomy } \\
\hline Subtotal & 182 & $179(64.1)$ & $3(60)$ & $p_{1}>0.999$ \\
\hline Total & 102 & $100(35.9)$ & $2(40)$ & \\
\hline Omental size $\left(\mathrm{cm}^{3}\right)^{\&}$ & - & $720(11.5-6,075)$ & $1,087(595-3,81)$ & $p_{2}=0.331$ \\
\hline Harvested LN \& & $41.2(15-114)$ & $41.1(15-114)$ & $47.2(31-73)$ & $p_{2}=0.332$ \\
\hline Positive harvested LN \& & $4.7(0-53)$ & $4.4(0-53)$ & $20.8(4-31)$ & $p_{2}=0.001$ \\
\hline Patients with omental LN \& & $66(23)$ & $61(22)$ & $5(100)$ & \\
\hline No. omental LN \& & $0(1-6)$ & $0(1-6)$ & $0(1-3)$ & \\
\hline No. positive omental LN & 5 & 0 & $5(100)$ & \\
\hline
\end{tabular}

(\%); $\mathrm{p}_{1}=$ Fisher's exact test; $\mathrm{p}_{2}=$ Mann-Whitney's test; $\mathrm{p}_{3}=$ Qui-square test; ${ }^{*}=$ one patient undetermined; $\&=$ values are mean(range) 
TABLE 4 - Correlation between the presence of metastatic lymph nodes in the omentum and patient status

\begin{tabular}{|c|c|c|c|}
\hline \multirow[b]{2}{*}{ Patient status } & \multicolumn{2}{|c|}{ Metastatic omental LN } & \\
\hline & No $(n=224)$ & Yes $(n=4)^{*}$ & \\
\hline \multicolumn{4}{|l|}{ Recurrence } \\
\hline No & $163(72.8)$ & $0(0)$ & \multirow{2}{*}{$p=0.006$} \\
\hline Yes & $59(27.2)$ & $4(100)$ & \\
\hline \multicolumn{4}{|l|}{ Peritoneal } \\
\hline No & $197(87.9)$ & $1(25)$ & \multirow{2}{*}{$p=0.008$} \\
\hline Yes & $27(12.1)$ & $3(75)$ & \\
\hline \multicolumn{4}{|l|}{ Local } \\
\hline No & $196(87.5)$ & $4(100)$ & \multirow{2}{*}{$p>0.999$} \\
\hline Yes & $28(12.5)$ & $0(0)$ & \\
\hline \multicolumn{4}{|l|}{ Anastomosis } \\
\hline No & 222 (99.1) & $4(100)$ & $p>0.999$ \\
\hline Yes & $2(0.9)$ & $0(0)$ & \\
\hline \multicolumn{4}{|l|}{ Lymph node } \\
\hline No & 199 (88.8) & $4(100)$ & $p>0.999$ \\
\hline Yes & $25(11.2)$ & $0(0)$ & \\
\hline \multicolumn{4}{|l|}{ Distant } \\
\hline No & 205 (91.5) & $1(25)$ & \multirow{2}{*}{$p=0.003$} \\
\hline Yes & $19(8.5)$ & $3(75)$ & \\
\hline \multicolumn{4}{|l|}{ Liver } \\
\hline No & $211(94.2)$ & $2(50)$ & $p=0.023$ \\
\hline Yes & $13(5.8)$ & $2(50)$ & \\
\hline \multicolumn{4}{|l|}{ Lung } \\
\hline No & $222(99.1)$ & $3(75)$ & $p=0.052$ \\
\hline Yes & $2(0.9)$ & $1(25)$ & \\
\hline \multicolumn{4}{|l|}{ Ovary } \\
\hline No & $223(99.5)$ & $3(75)$ & $p=0.035$ \\
\hline Yes & $1(0.5)$ & $1(25)$ & \\
\hline \multicolumn{4}{|l|}{ Bone } \\
\hline No & $222(99.1)$ & $4(100)$ & $p>0.999$ \\
\hline Yes & $2(0.9)$ & $0(0)$ & \\
\hline \multicolumn{4}{|l|}{ Others \# } \\
\hline No & $221(98.7)$ & $3(75)$ & $p=0.069$ \\
\hline Yes & $3(1.3)$ & $1(25)$ & \\
\hline \multicolumn{4}{|l|}{ Outcome } \\
\hline Free of disease & $163(72.7)$ & $0(0)$ & \\
\hline Relapse under treatment & $14(6.3)$ & $1(25)$ & \\
\hline Death & $78(34.8)$ & $4(75)$ & $p=0.008$ \\
\hline Loss of follow-up & $24(10.7)$ & $0(0)$ & \\
\hline
\end{tabular}

$\mathrm{p}=$ Fisher's exact test; (\%); \#=brain, pleura; ${ }^{*}=$ the cause of death is unknown in one patient with positive lymph node in the omentum and therefore could not be attributed to disease relapse

DISCUSSION

Despite the great advances of the multimodal therapy that have led to greater OS, free-margin gastrectomy associated with adequate lymphadenectomy remain crucial components in $\mathrm{GC}$ surgery with curative intent. Once questioned, extended lymphadenectomy (D2) provides better local control of the disease, allows accurate staging and avoids the stage migration phenomenon. In addition, surgery leads to better overall longterm survival. $6,7,31$

Traditionally, TO is performed as a part of subtotal/total gastrectomy with lymphadenectomy. The complete removal of the greater omentum has been considered essential to ensure the elimination of micrometastasis ${ }^{23}$. However, there is no consensus regarding the real benefit of TO on survival improvement and relapse decrement.
Several experimental studies have reported that cancer cells sown in the peritoneal cavity preferentially grow in the omentum, specifically at the milky spots ${ }^{12,27}$. Besides, many researchers insist that the extra nodal expansion occurs in some metastatic LN, which means that cancer cells spread from the LN capsule to adjacent adipose tissue ${ }^{24}$

Conversely, the greater omentum contains zones with high concentrations of immune system cells that can contribute to remove foreign bodies and bacteria ${ }^{33}$. Yet, it reduces the possibility of intestinal adhesions, not only by creating a mechanical barrier between the bowel and the abdominal wall, but also due to the production of fibrinolytic factors by the mesenchymal cells ${ }^{5}$. Other possible advantages of the omental preservation are the decrease in operative time (mainly in minimally invasive surgery), the blood loss and the reduction of complications such as abdominal abscess, ascites, anastomotic leakage, ileus, wound infection and iatrogenic lesions of the mesocolon and colon $^{10,14,22}$. Moreover, several studies have demonstrated no difference in OS nor disease free survival (DFS) between total and partial omentectomy in GC surgery ${ }^{10,13,14,21,22}$. Kim et al. ${ }^{21}$ compared TO with PO in 146 patients operated by laparoscopy for advanced GC. Propensity score match analysis ( $T$ and N parameters) showed no difference between the groups regarding DFS (TO versus PO: $83.3 \%$ vs. $90.5 \%, p=0.442$ ).

Although that there are some studies that compared short/long-term outcomes, complications, relapse and survival between TO and PO in GC surgery, specific studies regarding the incidence of metastatic omental LN are lacking. Haverkamp et al. ${ }^{15}$ prospectively evaluated the presence of omental LN and tumor deposits in 50 patients undergoing gastrectomy for GC. One (2\%) had metastatic omental LN (stage IB) and four (8\%) omental tumor deposits (stages IB, IIA, IIB and IIIA). Patients with tumor deposits had significantly reduced 1-year DFS compared to patients without tumor deposits ( 0 vs. $58.7 \%$, $p=0.003)$. However, no significant difference in 1-year OS of was found ( 25.0 vs. $67.4 \%$, respectively, $p=0.079)$. The authors did not find any predictive factors for omental metastasis ${ }^{31}$.

On the other hand, another prospective trial named OMEGA analyzed the presence of omental metastasis in 100 patients. Metastasis were detected in five $(5 \%)$ patients (two with metastatic LN and three with tumor cell deposits). All of them were at least stage $\mathrm{pT} 3$ with macroscopically non-radical resection $(p<0.001)$. Yet, omental metastasis was also significantly correlated with linitis plastica or location in the proximal third of the stomach $(p=0.002)$, tumor diameter of $5 \mathrm{~cm}$ or larger, stage III-IV disease $(p=0.010)$ and $(y) p M 1$ category $(p<0.001)^{20}$.

The present study corroborates the OMEGA trial results. It was found a significant correlation with tumors larger than $5.25 \mathrm{~cm}$. Still, as well as the Japanese guidelines, all patients with omental LN metastasis were categorized as stage pT3/T4, which allows us to state that TO may be omitted in stage T1/ T2 tumors. In fact, patients with positive omental LN had very advanced disease and there was a significant correlation with $N$ stage $(p<0.001)$ and clinical stage $(p=0.022)$. Nevertheless, the vast majority of $\mathrm{pT} 3 / \mathrm{T} 4$ tumors were free of metastatic omental LN (pT3: 1 positive/93 negative; pT4: 4 positive/75 negative), suggesting that TO may be also avoided in many T3/T4 tumors. The heart of the matter is how to identify these patients preoperatively, as only tumor's size was the only risk factor associated with omental disease. Other significant parameters such as venous invasion growth $(p=0.003)$ could only be assessed postoperatively. The rarity of the incidence also suggests that other conditions may be involved with omental LN disease.

Another interesting aspect is the fact that omental LN metastasis was associated with recurrence $(p=0.006)$, site of recurrence (peritoneum: $p=0.008$; liver: $p=0.023$; ovary: $p=0.035)$ and death $(p=0.008)$. Figure 3 represents OS curve of patients according to clinical stage and patients with omental $\mathrm{LN}$ metastasis. It may be alleged that, when there is omental 
LN involvement, systemic disease is in course, with very dismal prognosis. The purpose of performing TO is to remove micro metastasis and therefore to avoid mostly peritoneal recurrence. As in all patients in this cohort TO was performed, it can be speculated that removing the entire omentum during radical gastrectomy does not prevent relapse and, above all, death.

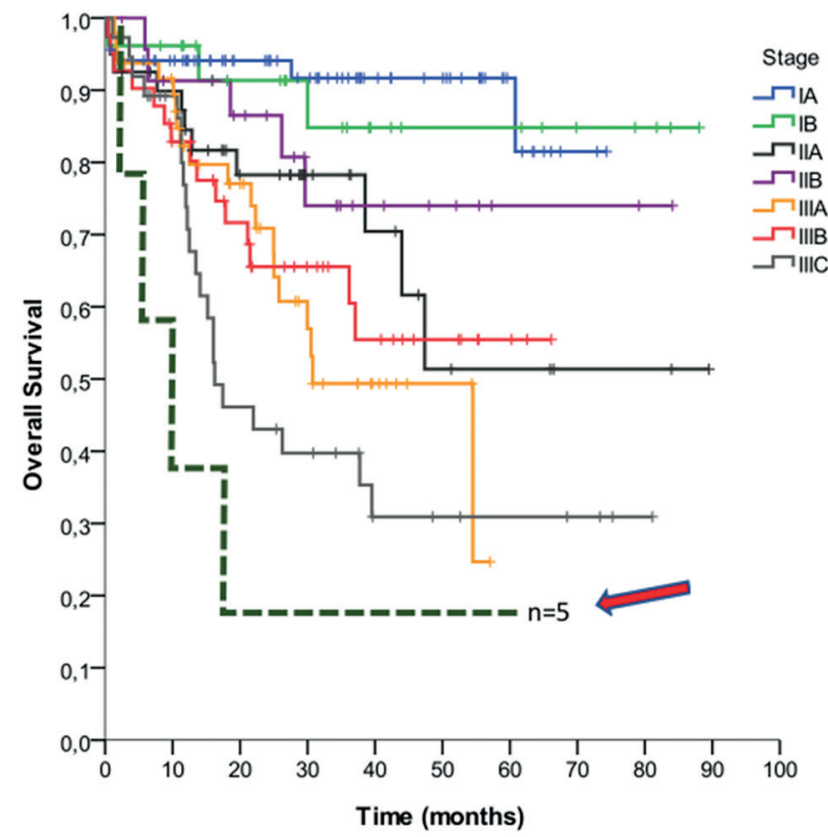

FIGURE 3 - Kaplan-Meier curve of survival: each line represents the OS of patients within a single clinical stage (TNM $7^{\text {th }}$ edition). The arrow indicates patients with omental metastatic LN

This study has some limitations. Firstly, five patients (three: stage pT4aN3aM1; one: pT4bN3M0 and one: pT3N2M0) with tumor deposits in the greater omentum were not included. There was not enough information whether metastatic omental involvement was diagnosed during surgery or through pathological analysis. Obviously, apart from identifying metastatic LN, to identify tumor deposits is essential to achieve R0 resection. In any case, the staging of these patients confirms that the omental disease is associated with advanced disease. Secondly, the oncotic cytology of peritoneal lavage was negative in all patients, similar to OMEGA trial. Some studies indicate up to $10 \%$ incidence of positive cytology in patients without peritoneal metastases ${ }^{25,29}$. Peritoneal cytology could be obtained in diagnostic laparoscopy and, certainly, would influence the decision to proceed with TO and possibly offer more aggressive treatments such as hyperthermia intraperitoneal chemotherapy, which is now under evaluation ${ }^{2,35}$.

\section{CONCLUSION}

The incidence of metastatic omental LN of patients undergoing radical gastrectomy due to GC is extremely low. Total omentectomy may be avoided in tumors smaller than $5.25 \mathrm{~cm}$ and T1/T2 tumors. However, lymph node metastasis in the greater omentum is associated with recurrence in the peritoneum, liver, ovary and death.

\section{ACKNOWLEDGMENTS}

The authors thanks Marina Alessandra Pereira, Carol Viviana Serna González and Cynthia Chiaradia for data collection and statistical support.
REFERENCES

1. Ajani JA, Barthel JS, Bekaii-Saab T, Bentrem DJ, D'Amico TA, Das P, et al. Gastric cancer. J Natl Compr Canc Netw [Internet]. 2010 Apr [cited 2018 Sep 24];8(4):378-409. Available from: http://www.ncbi.nlm.nih.gov/ pubmed/20410333

2. Badgwell B, Blum M, Das P, Estrella J, Wang $X, H o$ L, et al. Phase II Trial of Laparoscopic Hyperthermic Intraperitoneal Chemoperfusion for Peritoneal Carcinomatosis or Positive Peritoneal Cytology in Patients with Gastric Adenocarcinoma. Ann Surg Oncol [Internet]. 2017 Oct 10 [cited 2018 Sep 24];24(11):3338-44. Available from: http://www.ncbi.nlm.nih.gov/ pubmed/28799004

3. Barchi LC, Yagi OK, Jacob CE, Mucerino DR, Ribeiro U, Marrelli D, et al. Predicting recurrence after curative resection for gastric cancer. Eur J Surg Oncol [Internet]. 2016 Jan [cited 2018 Sep 24];42(1):123-31. Available from: http://www.ncbi.nlm.nih.gov/pubmed/26365755

4. Beelen RH. Roleofomental milky spots in thelocal immune response. Lancet (London, England) [Internet].1992Mar14[cited2018Sep24];339(8794):689. Available from: http://www.ncbi.nlm.nih.gov/pubmed/1347391

5. Cerci C, Eroglu E, Sutcu R, Celikbas B, Kilbas A. Effects of omentectomy on the peritoneal fibrinolytic system. Surg Today [Internet]. 2008 Aug 31 [cited 2018 Sep 24];38(8):711-5. Available from: http://www.ncbi.nlm.nih. gov/pubmed/18668314

6. Chen T, Yan D, Zheng Z, Yang J, Dong XDE. Evolution in the surgical management of gastric cancer: is extended lymph node dissection back in vogue in the USA? World J Surg Oncol [Internet]. 2017 Jul 17 [cited 2018 Sep 24];15(1):135.Availablefrom:http://www.ncbi.nlm.nih.gov/pubmed/28716043

7. Degiuli M, De Manzoni G, Di Leo A, D’Ugo D, Galasso E, Marrelli D, et al. Gastriccancer:Currentstatus oflymphnodedissection.WorldJGastroenterol [Internet]. 2016 Mar 14 [cited 2018 Sep 24];22(10):2875-93. Available from: http://www.ncbi.nlm.nih.gov/pubmed/26973384

8. Edge S, Byrd D, Carducci M, Compton C. AJCC - Cancer Staging Manual [Internet]. 7th ed. Springer, editor. New York, NY; 2009 [cited 2018 Sep 24]. Availablefrom:https://cancerstaging.org/references-tools/deskreferences/ Pages/default.aspx

9. Fujita J, Tsukahara Y, Ikeda K, Akagi K, Kan K, Hata S, et al. Evaluation of Omentum Preserving Gastrectomy for Advanced Gastric Cancer.Japanese J GastroenterolSurg[Internet].2003 [cited2018Sep24];36(8):1151-8.Available from:http://joi.jlc.jst.go.jp/JST.Journalarchive/jjgs1969/36.1151?from=CrossR ef10. Ha TK, An JY, Youn HG, Noh JH, Sohn TS, Kim S. Omentum-Presenving Gastrectomy for Early Gastric Cancer. World J Surg [Internet]. 2008 Aug 7 [cited 2018 Sep 24];32(8):1703-8. Available from: http://www.ncbi.nlm.nih. gov/pubmed/18536863

10. Hagiwara A, Sawai K, Sakakura C, Shirasu M, Ohgaki M, Yamasaki J, et al. Completeomentectomyandextensivelymphadenectomywith gastrectomy improves the survival of gastric cancer patients with metastases in the adjacent peritoneum. Hepatogastroenterology [Internet]. [cited 2018 Sep 24];45(23):1922-9. Available from: http://www.ncbi.nlm.nih.gov/ pubmed/9840177

11. Hagiwara A, Takahashi T, Sawai K, Taniguchi H, Shimotsuma M, Okano S, et al. Milky spots as the implantation site for malignant cells in peritoneal dissemination in mice. Cancer Res [Internet]. 1993 Feb 1 [cited 2018 Sep 24];53(3):687-92.Availablefrom:http://www.ncbi.nlm.nih.gov/pubmed/8425204

12. Hasegawa S, Kunisaki C, Ono H, Oshima T, Fujii S, Taguri M, et al. Omentumpreserving gastrectomy for advanced gastric cancer: a propensity-matched retrospective cohort study. Gastric Cancer [Internet]. 2013 Jul 17 [cited 2018 Sep 24];16(3):383-8. Available from: http://www.ncbi.nlm.nih.gov/ pubmed/22983455

13. Hasegawa S, Yamamoto Y, Taguri M, Morita S, Sato T, Yamada R, et al. A Randomized Phase II Trial of Omentum-preserving Gastrectomy for Advanced Gastric Cancer. Jpn J Clin Oncol [Internet]. 2013 Feb 1 [cited 2018 Sep 24];43(2):214-6. Available from: http://www.ncbi.nlm.nih.gov/ pubmed/23242583

14. Haverkamp L, Brenkman HJF, Ruurda JP, Ten Kate FJW, van Hillegersberg R. The Oncological Value of Omentectomy in Gastrectomy for Cancer. J GastrointestSurg [Internet].2016[cited2018Sep24];20(5):885-90.Available from: http://www.ncbi.nlm.nih.gov/pubmed/26895951

15. Hur H, Lee HY, Lee H-J, Kim MC, Hyung WJ, Park YK, et al. Efficacy of laparoscopic subtotal gastrectomy with D2 lymphadenectomy for locally advancedgastriccancer:theprotocoloftheKLASS-02multicenterrandomized controlled clinical trial. BMC Cancer [Internet]. 2015 May 5 [cited 2018 Sep 24];15:355.Availablefrom:http://www.ncbi.nlm.nih.gov/pubmed/25939684

16. Inaki N, Etoh T, Ohyama T, Uchiyama K, Katada N, Koeda K, et al. A Multiinstitutional, Prospective, Phase II Feasibility Study of Laparoscopy-Assisted Distal Gastrectomy with D2 Lymph Node Dissection for Locally Advanced Gastric Cancer (JLSSG0901). World J Surg [Internet]. 2015 Nov 14 [cited 2018 Sep 24];39(11):2734-41. Available from: http://www.ncbi.nlm.nih. gov/pubmed/26170158

17. JacobC,Gama-RodriguesJ,ZilbersteinB.Câncergástricoprecoce:complicações emortalidadeapósgastrectomiaelinfadenectomiaregrada:experiênciacom 178casosemumaúnicainstituição.ABCDArqBrasCirDig.2006;19(4):146-52. 
18. Japanese Gastric Cancer Association JGC. Japanesegastric cancertreatmen guidelines 2014 (ver. 4). Gastric Cancer [Internet]. 2017 Jan [cited 2018 Sep 24];20(1):1-19.Availablefrom:http://www.ncbi.nlm.nih.gov/pubmed/27342689

19. Jongerius E, Boerma D, Seldenrijk KA, Meijer SL, Scheepers JJG, Smedts F, et al. Role of omentectomy as part of radical surgery for gastric cancer. $\mathrm{Br}$ J Surg [Internet]. 2016 Oct [cited 2018 Sep 24];103(11):1497-503. Available from: http://www.ncbi.nlm.nih.gov/pubmed/27550526

20. Kim D, Lee J, Kim W. A comparison of total versus partial omentectomy for advanced gastric cancer in laparoscopic gastrectomy. World J Surg Oncol [Internet]. 2014 Mar 26 [cited 2018 Sep 24];12(1):64. Available from: http:// www.ncbi.nlm.nih.gov/pubmed/24669875

21. Kim M-C, Kim K-H, Jung GJ, Rattner DW. Comparative study of complete and partial omentectomy in radical subtotal gastrectomy for early gastric cancer. Yonsei Med J [Internet]. 2011 Nov [cited 2018 Sep 24];52(6):961-6. Available from: http://www.ncbi.nlm.nih.gov/pubmed/22028160

22. Lawrance RJ, Loizidou M, Cooper AJ, Alexander P, Taylor I. Importance of the omentum in the development of intra-abdominal metastases. Br J Surg [Internet]. 1991 Jan [cited 2018 Sep 24];78(1):117-9. Available from: http:// www.ncbi.nlm.nih.gov/pubmed/1998851

23. Lee I-S, Park Y-S, Ryu M-H, Song MJ, Yook J-H, Oh S-T, et al. Impact of extranodal extension on prognosis in lymph node-positive gastric cancer. BrJSurg [Internet].2014Nov [cited2018Sep24];101(12):1576-84. Available from: http://doi.wiley.com/10.1002/bjs.9640

24. LeeSD, Ryu KW, EomBW, LeeJH,KookMC, Kim Y-W.Prognosticsignificance of peritoneal washing cytology in patients with gastric cancer. Br J Surg [Internet]. 2012 Mar [cited 2018 Sep 24];99(3):397-403. Available from: http://www.ncbi.nlm.nih.gov/pubmed/22101572

25. Meza-PerezS, RandallTD.Immunological FunctionsoftheOmentum. Trends Immunol [Internet]. 2017 Jul [cited 2018 Sep 24];38(7):526-36. Available from: http://www.ncbi.nlm.nih.gov/pubmed/28579319

26. Oosterling SJ, van der Bij GJ, Bögels M, van der Sijp JRM, Beelen RHJ, Meijer $\mathrm{S}$, etal. Insufficientability of omental milky spots to preventperitoneal tumor outgrowthsupportsomentectomyinminimalresidualdisease.Cancerlmmuno Immunother [Internet]. 2006 Sep 26 [cited 2018 Sep 24];55(9):1043-51. Available from: http://www.ncbi.nlm.nih.gov/pubmed/16311732

27. Pereira MA, Ramos MFKP, Dias AR, Yagi OK, Faraj SF, Zilberstein B, et al. Detection of occult lymph node tumor cells in node-negative gastric cancer patients. ABCD Arq Bras Cir Dig (São Paulo) [Internet]. 2017 Mar [cited 2018 Sep 24];30(1):30-4. Available from: http://www.scielo.br/scielo. php?script=sci_arttext\&pid=S0102-67202017000100030\&lng=en\&tlng=en

28. Ribeiro-JR U, Safatle AR, Zilbertein B, Mucerino D, Yagi O, C B, et al. Does the Intraoperative Peritoneal Lavage Cytology Add Prognostic Information in Patients With Potentially Curative Gastric Resection? J Gastrointest Surg [Internet]. 2006 Feb [cited 2018 Sep 24];10(2):170-7. Available from: http:// www.ncbi.nlm.nih.gov/pubmed/16455447
29. Sasako M, Sakuramoto S, Katai H, Kinoshita T, Furukawa H, Yamaguchi T, et al. Five-Year Outcomes of a Randomized Phase III Trial Comparing Adjuvant Chemotherapy WithS-1 Versus Surgery Alone in Stage II or III Gastric Cancer. J Clin Oncol [Internet]. 2011 Nov 20 [cited 2018 Sep 24];29(33):4387-93. Available from: http://www.ncbi.nlm.nih.gov/pubmed/22010012

30. Songun I, Putter H, Kranenbarg EM-K, Sasako M, van de Velde CJ. Surgical treatment of gastric cancer: 15-year follow-up results of the randomised nationwide Dutch D1D2 trial. Lancet Oncol [Internet]. 2010 May [cited 2018 Sep 24];11(5):439-49. Available from: http://www.ncbi.nlm.nih.gov/ pubmed/20409751

31. TonetoMG, ViolaL.Currentstatusofthemultidisciplinarytreatmentofgastric adenocarcinoma. ABCD Arq Bras Cir Dig (São Paulo) [Internet]. 2018 Jul 2 [cited 2018Sep 24];31(2):e1373. Available from: http://www.scielo.br/scielo. php?script=sci_arttext\&pid=S0102-67202018000200504\&lng=en\&tIng=en

32. UzunköyA, Ozbilge $H$, HorozM. The influence of omentectomy on bacterial clearance: an experimental study. Ulus Travma Acil Cerrahi Derg [Internet]. 2009 Nov [cited 2018 Sep 25];15(6):541-5. Available from: http://www.ncbi. nlm.nih.gov/pubmed/20037870

33. VanCutsemE,DicatoM,GevaR,ArberN,BangY,BensonA, etal.Thediagnosis andmanagementofgastriccancer:expertdiscussionandrecommendations fromthe 12thESMO/World Congresson Gastrointestinal Cancer, Barcelona, 2010. Ann Oncol [Internet]. 2011 Jun 1 [cited 2018 Sep 24];22(Supplement 5):v1-9. Available from: http://www.ncbi.nlm.nih.gov/pubmed/21633049

34. Van der Kaaij RT, Braam HJ, Boot H, Los M, Cats A, Grootscholten C, et al. Treatment of Peritoneal Dissemination in Stomach Cancer Patients With Cytoreductive Surgery and Hyperthermic Intraperitoneal Chemotherapy (HIPEC): Rationale and Design of the PERISCOPE Study. JMIR Res Protoc [Internet]. 2017 Jul 13 [cited 2018 Sep 24];6(7):e136. Available from: http:// www.ncbi.nlm.nih.gov/pubmed/28705789

35. Watanabe N, Nashimoto A, Yabusaki H, Takii Y, Tsuchiya Y, Tanaka O. Evaluation of omento-bursectomy for $t 2$ and $t 3$ gastric cancers. Nihon Rinsho Geka Gakkai Zasshi (Journal Japan Surg Assoc [Internet]. 2004 Oct 25 [cited 2018 Sep 24];65(10):2570-4. Available from: http://joi.jlc.jst.go.jp/ JST.Journalarchive/ringe1998/65.2570?from=CrossRef

36. Zilberstein B, Malheiros C, Lourenco LG, Kassab P, Jacob CE, Weston AC, et al. Consenso brasileiro sobre câncer gástrico: diretrizes para o câncer gástrico no Brasil. ABCD Arq Bras Cir Dig (São Paulo) [Internet]. 2013 Mar [cited 2018 Sep 24];26(1):2-6. Available from: http://www.scielo.br/scielo. php?script=sci_arttext\&pid=S0102-67202013000100002\&lng=pt\&tlng=pt

37. Zilberstein B, Mucerino DR, Yagi OK, Ribeiro-Junior U, Lopasso FP, Bresciani C, et al. Resultados da gastrectomia D2 para o câncer gástrico: dissecção da cadeia linfática ou ressecção linfonodal múltipla? ABCD Arq Bras Cir Dig (São Paulo) [Internet]. 2012 Sep [cited 2018 Sep 24];25(3):161-4. Available from: http://www.scielo.br/scielo.php?script=sci_arttext\&pid=S010267202012000300005\&lng=pt\&tlng=pt 